University of Michigan Law School

University of Michigan Law School Scholarship Repository

Articles

Faculty Scholarship

1917

\title{
What Service Gives Jurisdiction in Person
}

John R. Rood

University of Michigan Law School

Available at: https://repository.law.umich.edu/articles/1356

Follow this and additional works at: https://repository.law.umich.edu/articles

Part of the Jurisdiction Commons, State and Local Government Law Commons, and the Supreme Court of the United States Commons

\section{Recommended Citation}

Rood, John R. (1904-1918). "What Service Gives Jurisdiction in Person." Mich. L. Rev. 15 (1917): 493-7.

This Response or Comment is brought to you for free and open access by the Faculty Scholarship at University of Michigan Law School Scholarship Repository. It has been accepted for inclusion in Articles by an authorized administrator of University of Michigan Law School Scholarship Repository. For more information, please contact mlaw.repository@umich.edu. 
What Service Gives JuRisdiction in Person.-On March 6th, IgI7, the Supreme Court of the United States, in the case of McDonald v. Mabee, reversing the decision of the Supreme Court of Texas, in $175 \mathrm{~S}$. W. 676 , held that a judgment in foreclosure proceedings in which the defendant was served only by publication did not merge the cause of action so as to bar a suit on the original notes for the balance unpaid by the sale of the mortgaged property on the foreclosure, although the statute of the state declared such service sufficient to give jurisdiction in personam, and the defendant was a citizen of the state and bound by the law so far as it was constitutional. The only case in the United States squarely sustaining the Texas decision on similar facts, so far as the writer is aware, is the often cited case of Henderson v. Staniford (1870), x05 Mass. 504, 7 Am. Rep. 551, in which it was held that action on the original cause was barred by the plaintiff recovering a judgment in a suit in California, where the parties resided, and in which the defendant was served only by publication. The court said that if the service so made was defective the defendant could waive the defect, and did so by urging the judgment as a defence. It is no doubt true that a defendant can waive service by appearing in the suit, as is done every day; but this defendant did and proposed no such thing; and no appearance by hin even if made could cure the defect unless such appearance were entered before judgment, so as to confer jurisdiction on the court to render the judgment. That a judgment recovered by such service was no bar, and was not available as a defence against a new action on the original cause, had, at the time this decision was rendered, been held in other states. Whittier $\nabla$. Wendell (1834), 7 N. H. 257; Middlesex Bank v. Butman (1848), 29 Me. 19. Thus considered, the decision of the Supreme Court of the United States in McDonald v. Mabee would seem to affirm a doctrine sufficiently clear on principle to require neither proof nor precedent to support it, were it not for the decisions to the contraty cited. But these decisions are not so contrary as they seem; fot they were tendered 
on the assumption that such a service gives jurisdiction, and it is in that regard that the present case is of the greatest interest.

The notion has persisted in many quarters that statutes may enable courts to acquire jurisdiction to give judgments in personam against persons who have neither appeared nor been served with personal notice within the jurisdiction to appear and defend, whereby to put them in default. There are the cases of Lucas $\nabla$. Wilson (I88I), $67 \mathrm{Ga}$. 356, and Hulbert v. Thomas (1887), 55 Conn. 18r, 1o Atl. 556, 3 Am. St. Rep. 43, in which judgments rendered on such service were affirmed in the Supreme Court because the requirements of the statute had been complied with, no inquiry being raised as to whether or not the statutes were constitutional. Then there are such cases as Nelson $\nabla$. Chicago, B. \& Q. Ry. Co. (1907), $225 \mathrm{Ill}$. I97, 80 N. E. 109, in which it was held that judgment against a corporation on such service was good because such was the service provided by the statute, and the defendant by citizenship is bound by the laws of the state. The facts are that the defendant was an Illinois corporation, agreeing to be bound by such service by consenting to be a corporation under that law, and therefore bound by the agreed method of service. The same would be true if it were a foreign corporation and accepted the permission given by the state to do business in the state on condition of consenting to accept service of that sort. The same would be true of a natural person who gives a judgment note, providing that if not paid when due the payee may appoint an agent to appear and confess judgment against the maker to the amount of the note, interest, and costs. Such a judgment is valid, not because the legislature could legalize such a method of-service, but because the party has expressly agreed to be bound by such service. It has been suggested that the same logic applies to natural persons, that by consenting to be citizens of the state they agree.to be bound by its laws; but that is not true, they are citizens whether they will or no. We were not consulted as to whom we would choose for parents or where we preferred to be born, assuming that we could have made a legal choice at that time. Even Mr. Justice Field's concession in Pennoyer v. Neff (I877), 95 U. S. 7 74 , 735, that a statute of a state providing that non-residents doing a partnership business in the state should be bound by indirect service, has since been repudiated, because such legislation denies equal protection of the law. Flesner v. Farson (I9I5), 268 I1l. 435,109 N. E. 327.

In the English courts it is quite clearly established that legislation providing for less than personal notice to confer jurisdiction in personam is valid, and will be given effect. Thus there is the leading case of Douglas v. Forrest (1824), 4 Bing. (I3 E. C. L.) 686, an action on a Scotch judgment against a Scotchman, in which it was held that a service consisting only of calling him in open court, at separate terms, to appear and calling in public in the market-square of Edinburgh and at the sea-shore after he had gone to India, was sufficient to give the court jurisdiction to render judgment against him in personam which would sustain an action of debt in England, because the service was according to the law of Scotland, to which the de- 
fendant owed allegiance. Again, in Bocquet v. MacCarthy (1831), 2 Barn. \& Ad. (22 E. C. L.) 951 , it was held that a statute of a British colony providing that in all actions against an absent party process might be served by delivering the same to the king's attorney, without requiring him to forward it to the party, was not so repugnant to the principles of natural justice as to prevent the English court maintaining an action of debt on a judgment rendered by a court of the colony against a citizen of the colony on such a service. The same has been held in an Irish court of a French judgment of France: Maubourquet v. Wyse (1867), I Ir. Rep. C. L. 47I.

But the writer has always maintained that these decisions do not express the accepted law of the United States, and that here no state can confer on its courts jurisdiction to render judgments in personam on any less service than personal service on the party to be charged, and that within the confines of the state. This view is supported by the decisions of the Supreme Court of the United States, first in the case of Webster v. Reid ( 1850 , II How. ( 52 U. S.) 437 , in which plaintiff claimed title to land by sale under execution on a judgment recovered for service of the commissioners appointed to partition the half-breed Indian lands, I19,000 acres. The commissioners not being paid for their services sued "The Owners of the Half-Breed Indian Lands," had process served by publication according to the law of the territory, took judgment for the amount of their services, had execution levied on all the lands, had them sold, and Reid claimed title by virtue of such sale. The court held the judgment and sale void, and Mr. Justice McLean in giving the opinion of the court said: "These suits were not a proceeding in rem against the land, but were in personam against the owners of it. Whether thcy all resided within the territory or not does not appear, nor is it a matter of any importance. No person is required to answer in a suit on whom process has not been served, or whose property has not been attached. In this case there was no personal notice, nor an attachment or other proceeding against the land until after the judgments. The judgments, therefore, are mere nullities and did not authorize the executions on which the land was sold." The observation that the rule is the same as to citizens and non-residents is worthy of particular note; and the same sentiment was emphatically repeated by Mr. Justice Field in Pennoyer $\nabla$. Neff (1877), 95 U. S. 714 But because the defendant in that case happened to be a -non-resident, many persons have said the decision might have been different had the defendant been a citizen of the state, basing their opinions on the English decisions above referred to, and the notion that the state may provide some substitute for personal service in the case of its own citizens. This qualification has been most explicitely denied in the Supreme Court of California in DeLaMontanya v. DeLaMontanya (1896), II2 Cal. I01, 44 Pac. 345, $53 \mathrm{Am}$. St. 165, 32 L. R. A. 82, holding void a decree for alimony and custody of children against a citizen of the state. on service by publication according to the requirements of a statute declaring that such service should be sufficient to give jurisdiction in personam; and similar rulings have been made in other states: Rahar v. Rahar (I9II), I50 Iowa 511, 129 N. W. 494, Ann. Cas. 1912D, 680; Moss v. Fitch (I908), 212 
Mo. 484, III S. W. 475, I26 Am. St. 568. In Smith v. Grady (1887), 68 Wis. 215,31 N. W. 477 , it was held that a judgment against a citizen of Ontario rendered on service on the debtor personally in the state of Wisconsin, in compliance with the laws of Ontario was not entitled to respect sufficient to prove a claim against the estate of the defendant therein in the probate courts of Wisconsin. In Grubel v. Nassaner (Ig13), 210 N. Y. 149, IO3 N. E. III3, it was held that an action was not maintainable on a judgment rendered by a court of the German Empire against a citizen of Germany on service according to the law of that country, after he had sailed to America.

1 In Wilson v. Seligman (1892), 144 U. S. 45, 12 Sup. Ct. 54r, after return of execution unsatisfied against a corporation, an order was made on motion, according to the provisions of the statute of the state, that execution issue against the stockholders, including defendant as one, and notice of this motion was personally served on him outside of the state; he did not appear, and on default an order was made finding him to be a stockbolder and liable for the judgment, and awarding execution against him. The statute required "sufficient notice in writing to the persons sought to be charged." On this order action was brought against the defendant in this case, and judgment for defendant was affirmed on writ of error to the Supreme Court of the United States. Gray, J., * * "In the case at bar the defendant never resided in Missouri, and was not served with process within the state, either upon the original writ against the corporation or upon the motion for execution against him. He denies that he was a stockholder; and the question whether he was one was not tried or decided in the controversy between the plaintiff and the corporation, nor involved in the judgment recovered by one of those parties against the other. Under the statute of Missouri, and upon fundamental principles of jurisprudence, he is entitled to legal notice and trial of the issue before he can be charged with personal liability."

Amsbaugh v. Exchange Bank of Maquoketa (1885), 33 Kan. 100, 5 Pac. 384, was an action on two judgments rendered against defendant in the circuit court of Jackson County, Iowa, on process served there on defendant's wife at the house where he bad resided, a week after his departure with intent never to return. He left November 4 , and the processes were served November 12 and 14 following. Judgment for plaintiff reversed on error, because judgments were void. The court held that a judgment rendered on such service was not entitled to any respect in any other state even if the service was according to the law of the state where it was rendered; because defendant had abandoned his residence before process was served, and therefore was beyond the jurisdiction.

Ross v. Fitch (1908), 212 Mo. 484, III S. W. 475, 126 Am. St. 568, was a decree for divorce, alimony, and custody of children, on process served only on defendant personally in another state, according to the law of this state; and sale of land on execution thereon. The divorce purchaser at the sale sued to clear sale of land on execution "Thereon. mind the legislature had no intent of giving the the title. GrAves, J. "To our mind the legislature had no intent of giving the providing another method of accomplishing the same thing; $i$.e., giving some kind providing another method of accompled the res, whether that res was property or the marriage status, and would proceed to determine the rights of the parties in and to the res.. * We repeat that, whatever may be the holdings elsewhere, our court places the acquisition of jurisdiction upon which a personal judgment can be rendeted upon the fact of personal service of the party with process in this state. In other words, no process issued by the courts of this state and served upon the party defendant in another state can be the basis of a personal judg. ment. And this is true whether the party in fact is a citizen of this state or of another stats" 
In rendering the opinion in the case of McDonald v. Mabee, Mr. Justice HoLMES makes a concession not heretofore admitted by the Supreme Court of the United States, that something a little short of personal service might constitute due process of law, within the protection of he constitution. This concession may be due to the fact that there are to be found on the statute books of nearly all the states provision for service of process by leaving a copy at the residence of the defendant with some member of the family of suitable age and discretion. Mr. Justice Holmes says: "Perhaps in view of his technical position and the actual presence of his family in the state a summons left at his last and usual place of abode would have been enough. $* * *$ It is going to the extreme to hold such power gained by service at the last and usual place of abode." - The writer is not aware of any case in which the constitutionality of a statute providing for acquisition of jurisdiction by such mode of service has yet been sustained. J. R. R. 